\title{
EFEKTIFITAS PEMBERIAN BAHAN ORGANIK DAN PUPUK KANDANG TERHADAP PERTUMBUHAN DAN PRODUKSI JAGUNG MANIS (Zea mays saccharataSturt.) PADA TANAH INCEPTISOL
}

\author{
Iqbal $^{1}$. Iswahyudi ${ }^{2}$. Muhammad Syahril ${ }^{2}$ \\ ${ }^{1}$ Mahsiswa Program Studi Agroteknologi Fakultas Pertanian Universitas samudra \\ ${ }^{2}$ Dosen Program Studi Agroteknologi Fakultas Pertanian Universitas samudra \\ Email: Hasibuaniqbal18@gmail.com
}

\begin{abstract}
Abstrak
Penelitian ini bertujuan untuk mengetahui efektifitas pemberian bahan organik dan pupuk kandang terhadap pertumbuhan jagung manis (Zea mays saccarat Sturt) pada tanah Inceptisol. Penelitian ini dilakasanakan di Desa Meurandeh Dayah, Kecamatan Langsa Lama, Kota Langsa, pada bulan Juli sampai September 2020. Penelitian ini menggunakan Rancang Acak Lengkap (RAK) pola fakorial yang terdiri dari 2 faktor, yaitu: faktor jenis bahan organik (B) yang terdiri dari 3 taraf. $\mathrm{B}_{0}=$ (Kontrol) $\mathrm{B}_{1}=$ Ampas Jerami Padi dan $\mathrm{B}_{2}=$ (AmpasTebu) dan faktor pupuk kandang $(\mathrm{K})$ yang terdiri darii taraf $\mathrm{K}_{0}=$ (Kontrol), $\mathrm{K}_{1}=$ (Pupuk Kandang Sapi) $\mathrm{K}_{2}=$ (Pupuk Kandang Kambing) dan $\mathrm{K}_{3}=$ (Pupuk Kandang Ayam). Parameter yang diamati antara lain: tinggi tanaman dan diameter batang umur 15, 30 dan 45 HST, panjang tongkol, berat tongkol berklobot dan tanpa klobot pertanaman dan produksi perhektar. Hasil terbaik diperoleh pada perlakuan pemberian bahan organik ampas tebu $\left(\mathrm{B}_{2}\right)$. Hasil pengamatan terbaik diperoleh pada interaksi perlakuan pemberian bahan organik ampas tebu $\left(\mathrm{B}_{2}\right)$ dan kandang ayam $\left(\mathrm{K}_{3}\right)$.
\end{abstract}

Kata kunci: Bahan Organik, Inceptisol dan Jagung

\section{PENDAHULUAN}

Jagung manis (Zea mays saccharata Sturt.) merupakan salah satu komoditas pertanian yang sangat digemari oleh masyarakat untuk dikonsumsi karena rasanya yang enak dan manis juga banyak mengandung karbohidrat, protein dan lemak (Jumini $d k k$. 2011). Selain dijadikan makanan pokok atau kebutuhan primer dan sekunder oleh beberapa suku di Indonesia, jagung manis sering dijadikan cemilan oleh masyarakat dengan berbagai macam pengolahannya.

Di Indonesia produksi jagung manis ditingkat petani masih sangat rendah. Banyak kendala yang dihadapi dalam pengusahaan jagung manis, salah satunya adalah rendahnya kesuburan tanah dan mahalnya harga pupuk kimia (anorganik). Tanaman jagung manis merupakan tanaman yang responsif terhadap pemupukan. Pemupukan sangat penting karena menentukan tingkat pertumbuhan dan produksinya (Kresnatita, dkk. 2013). Dalam rangka memenuhi kebutuhan jagung manis sebagai tanaman pangan maka perlu dilakukan upaya peningkatan produksi baik melalui ekstensifikasi maupun intensifikasi pertanian (Saputra, 2015).

Inceptisol merupakan ordo tanah yang penyebarannya cukup luas di Indonesia. Menurut (Puslitbangtanak, 2003) bahwa jenis tanah ini diperkirakan memiliki luasan 70,52 juta/ha atau menempati $40 \%$ dari luas total daratan di Indonesia. Inceptisol adalah tanah muda dan mulai berkembang, profil pembentukannya agak lambat. Permasalahan pada tanah inceptisol untuk budidaya tanaman adalah tanahnya mengalami perkembangan lanjut, $\mathrm{pH}$ masam, kandungan nitrogen dan bahan organik rendah, dan kedalaman efektifnya dangkal hingga dalam (Resmann dkk, 2006)

Untuk mengatasi kendala budidaya tanaman jagung manis pada tanah inceptisol, maka perlu dilakukan penambahan unsur hara dengan pemberian bahan organik dan pupuk kandang. Penambahan bahan organik merupakan cara untuk mencukupi asupan nutrisi untuk proses budidaya tanaman dan memperbaiki sifat fisik, kimia maupun biologi tanah.Bahan organik adalah suatu bahan yang memiliki bentuk padat dan cair yang berasal dari tanaman atau hewan. Penggunaan bahan organik sebagai bahan alternatif untuk penggunaan pupuk organik, karena dapat memperbaiki sifat fisik, kimia dan biologi tanah (Parman, 2007).

Selain pemberian bahan organik, pupuk kandang juga dapat memperbaiki sifat fisik, kimia dan biologi tanah. Pupuk kandang adalah pupuk yang berasal dari kotoran hewan. Pupuk kandang digolongkan dalam pupuk organik yang memiliki banyak kelebihan sehingga sangat disukai petani untuk memperbaiki struktur dan tekstur tanah, menaikkan daya serap tanah terhadap air, 
menambahkan mikro organisme dalam tanah dan zat sumber makanan pada tanaman. Pupuk kandang terdiri dari pupuk kandang sapi, kambing dan ayam (Wiryanto, 2003).

\section{BAHAN DAN METODE PENELITIAN}

Penelitian ini telah dilaksanakan di Desa Meurandeh Dayah, Kecamatan Langsa Lama, Kota Langsa, Propinsi Aceh dengan ketinggian tempat $\pm 10 \mathrm{mdpl}$. Waktu penelitian dilaksanakan selama tiga bulan, yang dimulai dari bulan Juli sampai bulan September 2020. Adapun bahan yang digunakan dalam penelitian ini antara lain: tanah inceptisol pH 5,10 yang didapatkan dari Desa Pondok Kemuning, Kecamatan Langsa Baru Kota Langsa, benih jagung manis varietas Mb-01 Swet, polibag ukuran 40x60 $\mathrm{cm}$ dengan volume $10 \mathrm{~kg}$, pupuk kandang (sapi, kambing dan ayam), ampas tebu, jerami padi, Insektisida decis 25 EC, Effective Mikroorganisme (EM4), cat, paku, tali plastik, papan nama serta papan perlakuan. Sedangkan alat yang digunakan dalam penelitian ini meliputi: cangkul, parang, gunting, jangka sorong, timbangan digital, kamera, meteran, plastik ukuran 1x2m, karung volume $30 \mathrm{~kg}$, tali plastik, gembor dan alat tulis menulis. Peneletitian ini menggunakan rancangan acak kelompok (RAK) pola faktorial yang terdiri dari 2 faktor yaitu: Faktor jenis bahan organik (B) yang terdiri dari 3 taraf yaitu: $\mathrm{B}_{0}=$ Kontrol, $\mathrm{B}_{1}=$ Jerami padi (30 ton $\left./ \mathrm{ha}\right), \mathrm{B}_{2}=$ Ampas tebu (30 ton/ha). Faktor jenis pupuk kandang $(\mathrm{K})$ yang terdiri dari 4 taraf yaitu : $\mathrm{K}_{\mathrm{o}}=\mathrm{Kontrol}, \mathrm{K}_{1}=$ Pupuk Kandang Sapi(30 ton/ha), $\mathrm{K}_{2}=$ Pupuk Kandang kambing (30 ton/ha), $\mathrm{K}_{3}=$ Pupuk Kandang Ayam (30 ton/ha). Parameter yang diamati adalah tinggit tanaman, diameter pangkal batang, berat tongkol berkelobot pertanaman, berat tongkol tanpa berkelobot pertanaman, panjang tongkol, produksi per hektar.

\section{Tinggi Tanaman}

\section{HASIL DAN PEMBAHASAN \\ Pengaruh Bahan Organik}

Rata-rata tinggi tanaman jagung manis pada umur 30 dan 45 HST akibat pemberian bahan organik disajikan pada Tabel 1.

Tabel 1. Rata-rata Tinggi Tanaman Jagung Manis Pengaruh Bahan Organik.

\begin{tabular}{cccc}
\hline \multirow{2}{*}{ Perlakuan } & \multicolumn{3}{c}{ Tinggi Tanaman $(\mathrm{cm})$} \\
\cline { 2 - 4 } & $15 \mathrm{HST}$ & $30 \mathrm{HST}$ & $45 \mathrm{HST}$ \\
\hline $\mathrm{B}_{0}$ & 18,28 & $65,65 \mathrm{ab}$ & $118,11 \mathrm{a}$ \\
$\mathrm{B}_{1}$ & 19,07 & $59,72 \mathrm{a}$ & $116,10 \mathrm{a}$ \\
$\mathrm{B}_{2}$ & 19,59 & $73,96 \mathrm{~b}$ & $140,28 \mathrm{~b}$ \\
\hline $\mathrm{BNT}_{0,05}$ & $\mathrm{tn}$ & 8,50 & 10,40 \\
\hline
\end{tabular}

Keterangan : Angka yang diikuti oleh hurup yang sama pada kolom yang sama berbeda tidak nyata pada uji BNT pada taraf $5 \%$

Tabel 1 menunjukkan bahwa tinggi tanaman jagung manis tertinggi terdapat pada perlakuan $\mathrm{B}_{2}$ (ampas tebu). Hasil uji $\mathrm{BNT}_{0,05}$ pada umur 30 HST pada perlakuan $\mathrm{B}_{2}$ (ampas tebu) berbeda tidak nyata dengan perlakuan $B_{0}$ namun berbeda nyata dengan perlakuan $B_{1}$ (jerami padi). Pada umur 45 HST tinggi tanaman pada perlakuan $\mathrm{B}_{2}$ berbeda nyata dengan perlakuan $\mathrm{B}_{0}$ dan $\mathrm{B}_{1}$. Hal ini diduga karena kandungan hara yang terdapat pada ampas Tebu $\left(\mathrm{B}_{2}\right)$ memiliki kandungan $\mathrm{N}$ lebih tinggi dari pada ampas jerami padi $\left(\mathrm{B}_{1}\right)$ sedangkan kandungan hara yang terdapat pada ampas jerami padi memiliki kandungan $\mathrm{K}$ yang lebih tinggi sehingga tidak berpengaruh terhadap tinggi tanaman jagung manis.

Hal ini sesuai pendapat Sutanto (2005) bahwa unsur hara nitrogen yang terkandung dalam ampas tebu memberikan pengaruh nyata terhadap pertumbuhan tanaman yang dapat merangsang pertumbuhan akar, batang, daun dan tinggi tanaman.

\section{Diameter Pangkal Batang}

Rata-rata diameter batang jagung manis pada umur 30 dan 45 HST akibat pemberian bahan organik disajikan pada Tabel 2. 
Tabel 2. Rata-rata Diameter Pangkal Batang jagung Manis pengaruh Bahan Organik

\begin{tabular}{cccc}
\hline \multirow{2}{*}{ Perlakuan } & \multicolumn{3}{c}{ Diameter Batang $(\mathrm{cm})$} \\
\cline { 2 - 4 } & $15 \mathrm{HST}$ & $30 \mathrm{HST}$ & $45 \mathrm{HST}$ \\
\hline $\mathrm{B}_{0}$ & 0,54 & $1,40 \mathrm{a}$ & $2,12 \mathrm{a}$ \\
$\mathrm{B}_{1}$ & 0,79 & $1,30 \mathrm{a}$ & $1,95 \mathrm{a}$ \\
$\mathrm{B}_{2}$ & 0,97 & $1,72 \mathrm{~b}$ & $2,43 \mathrm{~b}$ \\
\hline BNT $_{0,05}$ & th & 0,18 & 0,21
\end{tabular}

Keterangan: Angka yang diikuti oleh huruf yang sama pada kolom yang sama berbeda tidak nyata pada uji BNT pada taraf $5 \%$.

Tabel 2 menunjukkan bahwa bahan organik berpengaruh nyata terhadap diameter batang umur 30 dan 45 HST. Hasil uji BNT ${ }_{0,05}$ pada umur 30 dan 45 HST perlakuan $\mathrm{B}_{2}$ berbeda nyata dengan perlakuan $\mathrm{B}_{0}$ dan $\mathrm{B}_{1}$. Sedangkan $\mathrm{B}_{1}$ dengan $\mathrm{B}_{0}$ tidak berbeda nyata. Hal ini diduga karena kandungan hara yang paling dibutuhkan pada pertumbuhan tanaman yaitu unsur hara N. Adapun kandungan unsur hara $\mathrm{N}$ tertinggi terdapat pada ampas tebu $\left(\mathrm{B}_{2}\right)$. Ampas jerami padi memiliki kandungan unsur $\mathrm{K}$ yang tinggi sehingga tidak berpengaruh nyata terhadap pertumbuhan tanaman.

Hal ini sesuai dengan pendapat Ningsih dkk (2015) bahwa nitrogen merupakan penyusun dari banyak senyawa seperti asam amino yang diperlukan dalam pembentukan atau pertumbuhan bagian-bagian vegetatif seperti akar, batang dan daun, sehingga dengan tersedianya nitrogen pada tanaman jagung, semua aktivitas sel berjalan dengan normal seperti pemanjangan batang oleh aktivitas sinyal dari hormon giberilin dan auksin yakni hormon pertumbuhan tanaman tersusun dari nitrogen.

\section{Berat Tongkol Berklobot Pertanaman}

Rata-rata berat tongkol berklobot pertanaman jagung manis akibat pemberian bahan organik disajikan pada Tabel 3.

Tabel 3 menunjukkan bahwa berat tongkol jagung manis berklobot tertinggi diperoleh perlakuan $\mathrm{B}_{2}$ yang secara uji BNT ${ }_{0,05}$ berbeda nyata dengan perlakuan $\mathrm{B}_{0}$ dan $\mathrm{B} 1$. Hal ini diduga karena unsur hara $\mathrm{P}$ sangat berperan terhadap penyempurnaan tongkol sehingga mampu meningkatkan berat bobot tongkol. Hal ini diduga karena kandungan unsur $\mathrm{P}$ pada ampas tebu lebih tinggi dari pada jerami padi. Hal ini sesuai dengan pendapat Marinda dkk (2016) bahwa ampas tebu mengandung air $52 \%, \mathrm{~N} 0,04 \%, \mathrm{P}, 0,05 \%$ dan $\mathrm{K} 0,02 \%$. Adapun jerami padi mengandung air $56 \% \mathrm{~N}$ $0,03 \%, \mathrm{P} 0,02 \%$ dan K $1,14 \%$. Dari beberapa unsur tersebut merupakan senyawa yang sangat mutlak dibutuhkan oleh tanaman dalam jumlah besar yang mampu meningkatkan produksi tanaman.

Tabel 3. Rata-rata Berat Tongkol Berklobot per Tanaman pengaruh Bahan Organik

\begin{tabular}{cc}
\hline Perlakuan & Berat Tongkol Berklobot Pertanaman (gr) \\
\hline $\mathrm{B}_{0}$ & $196,15 \mathrm{a}$ \\
$\mathrm{B}_{1}$ & $206,71 \mathrm{~b}$ \\
$\mathrm{~B}_{2}$ & $219,54 \mathrm{c}$ \\
\hline BNT $_{0,05}$ & 3,87
\end{tabular}

Keterangan: Angka yang diikuti oleh huruf yang sama pada kolom yang sama berbeda tidak nyata pada uji BNT pada taraf $5 \%$.

\section{Berat Tongkol Tanpa Klobot Per Tanaman}

Rata-rata berat tongkol tanpa klobot jagung manis akibat pemberian bahan organik disajikan pada Tabel 4.

Tabel 4 menunjukkan bahwa berat tongkol jagung manis tanpa klobot tertinggi diperoleh perlakuan $\mathrm{B}_{2}$ yang secara uji $\mathrm{BNT}{ }_{0,05}$ berbeda nyata dengan perlakuan $\mathrm{B}_{0}$ dan $\mathrm{B}_{1}$. Hal ini diduga karena kandungan unsur hara $\mathrm{P}$ yang tertinggi terdapat pada ampas tebu. Adapun pada jerami padi mengandung kandungan hara $\mathrm{K}$ yang tinggi sehingga sama-sama berperan terhadap pembentukan tongkol pada tanaman jagung manis. 
Tabel 4. Rata-rata Berat Tongkol tanpa klobot per Tanaman pengaruh Bahan Organik

\begin{tabular}{cc}
\hline Perlakuan & Berat Tongkol Tanpa Klobot Per tanaman (gr) \\
\hline $\mathrm{B}_{0}$ & $146,42 \mathrm{a}$ \\
$\mathrm{B}_{1}$ & $147,13 \mathrm{a}$ \\
$\mathrm{B}_{2}$ & $160,38 \mathrm{~b}$ \\
\hline $\mathrm{BNT}_{0,05}$ & 7,46
\end{tabular}

Keterangan: Angka yang diikuti oleh huruf yang sama pada kolom yang sama berbeda tidak nyata pada uji BNT pada taraf $5 \%$.

Marvelia dkk (2006) mengatakan bahwa unsur P berperan terhadap ukuran tongkol, karena tongkol merupakan perkembangan dari bunga betina dan buah sehingga sehingga untuk mendorong pembentukan bunga dan buah sangat diperlukan unsur $\mathrm{P}$.

\section{Panjang Tongkol}

Rata-rata pengaruh panjang tongkol akibat pemberian bahan organik disajikan padaTabel 5

Tabel 5. Rata-rata Panjang Tongkol pengaruh Bahan Organik

\begin{tabular}{|c|c|}
\hline Perlakuan & panjang Tongkol $(\mathrm{Cm})$ \\
\hline $\mathrm{B}_{0}$ & 19,23 \\
\hline $\mathrm{B}_{1}$ & 17,87 \\
\hline $\mathrm{B}_{2}$ & 18,90 \\
\hline $\mathrm{BNT}_{0,05}$ & Tn \\
\hline
\end{tabular}

Hal tersebut sesuai dengan pendapat Sitompul dkk (2000) bahwa penampilan tanaman dikendalikan oleh sifat genetik di bawah pengaruh faktor-faktor lingkungan. Kendali genetik pada penampilan tanaman diekspresikan melalui proses biokimia dan fisiologi

\section{Prduksi Per Hektar}

Rata-rata peroduksi perhektar akibat pemberian bahan organik disajikan pada Tabel 6.

Tabel 6 menunjukkan bahwa produksi perhektar tanaman jagung manis pengaruh bahan organik hasil tertinggi dijumpai pada perlakuan $\mathrm{B}_{2}$ diikuti dengan $\mathrm{B}_{1}$ dan $\mathrm{B}_{0}$. hasil uji BNT pada taraf ${ }_{0,05}$ diketahui bahwa produksi per hektar pada perlakuan $\mathrm{B}_{2}$ berbeda nyata dengan perlakuan $\mathrm{B}_{1}$ dan $\mathrm{B}_{0}$

Tabel 6. Rata-rata Produksi per Hektar Pengaruh Bahan Organik.

\begin{tabular}{cc}
\hline Perlakuan & Produksi perhektar (Ton) \\
\hline $\mathrm{B}_{0}$ & $13,08 \mathrm{a}$ \\
$\mathrm{B}_{1}$ & $13,78 \mathrm{~b}$ \\
$\mathrm{~B}_{2}$ & $14,63 \mathrm{c}$ \\
\hline $\mathrm{BNT}_{0,05}$ & 0,27 \\
\hline Keterangan: Angka yang diikuti oleh huruf yang sama pada kolom yang sama berbeda tidak nyata pada uji BNT pada \\
taraf $5 \%$.
\end{tabular}

Hal tersebut sesuai dengan pendapat Adnan (2015), bahwa dengan penambahan bahan organik ampas tebu sangat berperan dalam penambahan kandungan unsur P yang cukup tinggi, dibandingkan dengan ampas jerami padi, sehingga unsur paling tinggi pada ampas tebu sangat berperan dalam memperbaiki kualitas bobot tongkol tanaman jagung manis.

\section{Tinggi Tanaman}

\section{Pengaruh Pupuk Kandang}

Rata-rata tinggi tanaman jagung manis pada umur 30 dan 45 HST akibat pemberian pupuk kandang disajikan pada Tabel 7. 
Tabel 7. Rata-rata Tinggi Tanaman pengaruh Pupuk Kandang.

\begin{tabular}{cccc}
\hline \multirow{2}{*}{ Perlakuan } & \multicolumn{3}{c}{ Tinggi Tanaman $(\mathrm{cm})$} \\
\cline { 2 - 4 } & $15 \mathrm{HST}$ & $30 \mathrm{HST}$ & $45 \mathrm{HST}$ \\
\hline $\mathrm{K}_{0}$ & 15,12 & $34,54 \mathrm{a}$ & $55,69 \mathrm{a}$ \\
$\mathrm{K}_{1}$ & 20,59 & $87,48 \mathrm{c}$ & $169,55 \mathrm{c}$ \\
$\mathrm{K}_{2}$ & 20,35 & $84,58 \mathrm{c}$ & $167,81 \mathrm{c}$ \\
$\mathrm{K}_{3}$ & 19,87 & $59,18 \mathrm{~b}$ & $106,26 \mathrm{~b}$ \\
\hline BNT $_{0,03}$ & tn & 9,82 & 12,01 \\
\hline
\end{tabular}

Keterangan : Angka yang diikuti oleh huruf yang sama pada kolom yang sama berbeda tidak nyata pada uji BNT pada taraf $5 \%$

Tabel 7 menunjukkan bahwa tinggi tanaman jagung manis tertinggi didapatkan pada perlakuan $\mathrm{K}_{1}$ (pupuk kandang sapi), dari hasil uji BNT ${ }_{0,05}$ diketahui bahwa pada umur 30 dan 45 HST, perlakuan $\mathrm{K}_{1}$ berbeda nyata dengan perlakuan $\mathrm{K}_{0}$ (Kontrol) dan $\mathrm{K}_{3}$ (pupuk kandang ayam) namun tidak bebeda nyata dengan perlakuan $\mathrm{K}_{2}$ (pupuk kandang kambing).

Hal ini diduga karena pupuk kandang sapi dan kambing memiliki nilai kandungan unsur $\mathrm{N}$ yang sama-sama tinggi dan waktu penyediaan hara yang cukup lama sehingga berpengaruh sangat nyata pada tinggi tanaman umur 30 dan 45 HST dibandingkan pupuk kandang ayam yang penyediaan haranya lebih cepat sehingga mudah terjadinya pencucian

Menurut Mapegau (2010) bahwa unsur nitrogen dapat meningkatkan laju fotosintesis tanaman sehingga dapat memacu pertumbuhan vegetatif, hususnya akar, batang dan daun, karena nitrogen merupakan merupakan unsur hara penyusun asam amino, amida dan nukleo protein untuk pembelahan sel.

\section{Diameter Batang}

Rata-rata diameter batang akibat pemberian pupuk kandang pada tanaman jagung manis umur 15, 30 dan 45 HST disajikan pada Tabel 8.

Tabel 8. Rata-rata Diameter Pangkal Batang akibat Pemberian Pupuk kandang.

\begin{tabular}{cccc}
\hline \multirow{2}{*}{ Perlakuan } & \multicolumn{3}{c}{ Diameter Batang $(\mathrm{cm})$} \\
\cline { 2 - 4 } & $15 \mathrm{HST}$ & $30 \mathrm{HST}$ & $45 \mathrm{HST}$ \\
\hline $\mathrm{K}_{0}$ & 0,33 & $0,67 \mathrm{a}$ & $0,98 \mathrm{a}$ \\
$\mathrm{K}_{1}$ & 0,69 & $1,95 \mathrm{c}$ & $2,80 \mathrm{c}$ \\
$\mathrm{K}_{2}$ & 0,75 & $2,12 \mathrm{c}$ & $2,88 \mathrm{c}$ \\
$\mathrm{K}_{3}$ & 0,51 & $1,16 \mathrm{~b}$ & $2,00 \mathrm{~b}$ \\
\hline BNT $_{0,03}$ & tn & 0,21 & 0,24 \\
\hline
\end{tabular}

Keterangan: Angka yang diikuti oleh huruf yang sama pada kolom yang sama berbeda tidak nyata pada uji BNT pada taraf $5 \%$.

Tabel 8 menunjukkan bahwa diameter batang jagung manis umur 30 dan 45 HST tertinggi dijumpai pada perlakuan $\mathrm{K}_{2}$ yang secara uji BNT 0,05 tidak berbeda nyata dengan perlakuan $\mathrm{K}_{1}$, namun berbeda nyata dengan perlakuan $\mathrm{K}_{0}$ dan $\mathrm{K}_{3}$. Hal ini diduga karena mikroba yang terdapat dalam pupuk kandang sapi dan kambing lebih tinggi sehingga tersedianya unnsur nitrogen secara terus menerus sehingga perpengaru terhadap diameter batang umur 30 dan 45 HST.

Adapun pendapat Simanungkalit dkk (2006) menyatakan bahwa mikroba yang terkandung dalam pupuk kandang sapi dan kambing memiliki nilai tertinggi dibandingkan pupuk kandang ayam. Hal ini disebabkan kandungan air yang terdapat pada pupuk kandang sapi dan kambing memicu pertumbuhan mikroba, Sehingga mikroba yang terdapat pada pupuk kandang mampu melarutkan beberapa unsur hara terutama unsur nitrogen. 


\section{Berat Tongkol Berklobot per Tanaman}

Rata-rata berat tongkol berklobot pertanaman disajikan pada Tabel 9.

Tabel 9. Rata-rata Berat Tongkol Berklobot per Tanaman akibat pemberian Pupuk Kandang.

\begin{tabular}{lc}
\hline Perlakuan & Berat Tongkol Berklobot per Tanaman (gr) \\
\hline $\mathrm{K}_{0}$ & $111,00 \mathrm{a}$ \\
$\mathrm{K}_{1}$ & $230,28 \mathrm{~b}$ \\
$\mathrm{~K}_{2}$ & $239,94 \mathrm{c}$ \\
$\mathrm{K}_{3}$ & $248,61 \mathrm{c}$ \\
\hline
\end{tabular}

BNT $_{0,03} \quad 4,47$

Keterangan: Angka yang diikuti oleh huruf yang sama pada kolom yang sama berbeda tidak nyata pada uji BNT pada taraf $5 \%$.

Tabel 9 menunjukkan bahwa berat tongkol berklobot pada tanaman jagung manis tertinggi dijumpai pada perlakuan $\mathrm{K}_{3}$ yang secara uji BNT ${ }_{0.05}$ berbeda nyata dengan perlakuan $\mathrm{K}_{0}$ dan $\mathrm{K}_{1}$, namun tidak berbeda nyata dengan perlakuan $\mathrm{K}_{2}$. Hal ini diduga karena kandungan unsur $\mathrm{P}$ yang terdapat dalam pupuk kandang kambing dan ayam memiliki peranan yang sama sehingga tidak memberikan pengaruh nyata, adapun kandungan $\mathrm{P}$ yang terdapat dalam pupuk kandang sangat berpengaruh terhadap pembentukan tongkol, kemudian apabila ketersediaan kandungan fosfat dalam tanah tercukupi maka pembentukan tongkol berhasil secara sempurna.

Pupuk kandang kambing dan ayam merupakan penghasil kandungan fosfat yang cukup tinggi sehingga berpengaruh nyata terhadap berat tongkol berklobot pertanaman. Hal ini sesuai dengan pendapat Wahyuni (2017) bahwa kandungan P pupuk kandang mampu menyempurnakan pembungaan dan pembentukan buah secara sempurna untuk meningkat produksi hasil tanaman jagung manis.

\section{Berat Tongkol Tanpa Klobot per Tanaman}

Rata-rata berat tongkol tanpa klobot pertanaman disajikan pada Tabel 10. Tabel 10 menunjukkan bahwa berat tongkol tanpa klobot hasil tertinggi dijumpai pada perlakuan $\mathrm{K}_{3}$ yang secara uji BNT 0,05 berbeda nyata dengan perlakuan $\mathrm{K}_{0}$ dan $\mathrm{K}_{1}$ namun tidak berbeda nyata dengan perlakuan $\mathrm{K}_{2}$. Hal ini diduga pengaruh kandungan unsur $\mathrm{P}$ pada pupuk kandang kambing dan ayam relatif tinggi sehingga berpengaruh terhadap pertumbuhan vegetatif tanaman jagung manis. Pengaruh ini terjadi pada pembentukan bunga betina dan biji pada tongkol jagung manis.

Tabel 10. Rata-rata Berat Tongkol tanpa Klobot per Tanaman.

\begin{tabular}{cc}
\hline Perlakuan & Berat Tongkol Tanpa Berklobot Pertanaman (Gram) \\
\hline $\mathrm{K}_{0}$ & $49,39 \mathrm{a}$ \\
$\mathrm{K}_{1}$ & $177,89 \mathrm{~b}$ \\
$\mathrm{~K}_{2}$ & $188,89 \mathrm{c}$ \\
$\mathrm{K}_{3}$ & $189,06 \mathrm{c}$ \\
\hline BNT $_{0,03}$ & 8,62 \\
\hline
\end{tabular}

Keterangan: Angka yang diikuti oleh huruf yang sama pada kolom yang sama berbeda tidak nyata pada uji BNT pada taraf $5 \%$.

Hal ini sesuai dengan pendapat Sidar (2010) bahwa kandungan hara P pada pupuk kandang diperlukan tanaman jagung manis pada fase pertumbuhan generatif dalam pembentukan tongkol apabila tanaman jagung manis kekurangan unsur hara tersebut maka akan menyebabkan perkembangan tongkol tidak sempurna dan menyebabkan biji tidak merata dan tidak bernas.

\section{Panjang Tongkol} Tabel 11

Rata-rata pengaruh pupuk kandang terhadap panjang tongkol jagung manis disajikan pada

Tabel 11 menunjukkan bahwa panjang tongkol tertinggi dijumpai pada perlakuan $\mathrm{K}_{1}$ yang secara uji $\mathrm{BNT}_{0,05}$ berbeda nyata dengan perlakuan $\mathrm{K}_{0}$, dan $\mathrm{K}_{2}$, namun tidak berbeda nyata dengan 
perlakuan $\mathrm{K}_{3}$. Hal ini diduga karena asam-asam organik yang dihasilkan mikroba yang terdapat dalam pupuk kandang mampu meningkatkan dan melarutkan $\mathrm{P}$ dalam tanah sehingga tanaman mampu menyerah unsur $\mathrm{P}$ secara sempurna, sehingga unsur $\mathrm{P}$ mampu meningkatkan pembentukan bobot panjang dan diameter tongkol jagung manis secara sempurna.

Wahyudin dkk (2017) menyatakan bahwa apabila tersedianya dan terserapnya unsur P menyebabkan fotosintat yang dialokasikan ke tongkol menjadi lebih banyak sehingga ukuran tongkol tanaman jagung manis terbentuk sempurna maka akan memberikan hasil produksi yang tinggi.

Tabel 11. Rata-rata pengaruh Pupuk Kandang terhadap panjang Tongkol Jagung Manis

\begin{tabular}{cc}
\hline Perlakuan & Panjang Tongkol $(\mathrm{Cm})$ \\
\hline $\mathrm{K}_{0}$ & $14,18 \mathrm{a}$ \\
$\mathrm{K}_{1}$ & $21,22 \mathrm{c}$ \\
$\mathrm{K}_{2}$ & $19,52 \mathrm{~b}$ \\
$\mathrm{~K}_{3}$ & $19,75 \mathrm{bc}$ \\
\hline BNT $_{0,05}$ & 1,49 \\
\hline Keterangan: Angka yang diikuti oleh huruf yang sama pada kolom yang sama berbeda tidak nyata pada uji BNT pada taraf \\
$5 \%$.
\end{tabular}

\section{Produksi Per Hektar}

Rata-rata pengaruh pupuk kandang terhadap produksi per hektar tanaman jagung manis disajikan pada Tabel 12.

Tabel 12. Rata-rata Pengaruh Pupuk Kandang terhadap Produksi Jagung Manis per Hektar.

\begin{tabular}{cc}
\hline Perlakuan & Produksi Per Hektar (Ton) \\
\hline $\mathrm{K}_{0}$ & $7,40 \mathrm{a}$ \\
$\mathrm{K}_{1}$ & $15,35 \mathrm{~b}$ \\
$\mathrm{~K}_{2}$ & $15,99 \mathrm{c}$ \\
$\mathrm{K}_{3}$ & $16,57 \mathrm{c}$ \\
\hline BNT $_{0,05}$ & 0,31 \\
\hline Keterangan: Angka yang diikuti oleh huruf yang sama pada kolom yang sama berbeda tidak nyata pada uji BNT pada \\
taraf 5\%.
\end{tabular}

Tabel 12 menunjukkan bahwa produksi perhektar tertinggi dijumpai pada perlakuan $\mathrm{K}_{3}$ yang secara uji BNT 0,05 berbeda nyata dengan perlakuan $\mathrm{K}_{0}$ dan $\mathrm{K} 1$, namun tidak berbeda nyata dengan perlakuan $\mathrm{K}_{2}$. Hal ini diduga karena kandungan unsur $\mathrm{N}$ yang tinggi pada pupuk kandang kambing dan kandungan unsur $\mathrm{P}$ yang tinggi pada pupuk kandang ayam sangat berpengaruh terhadap pertumbuhan dan produksi tanaman jagung manis.

Hal ini sesuai dengan pendapat Sholeha (2011) bahwa semakin tinggi nilai kandungan unsur hara yang terdapat pada pupuk kandang yang diberikan maka akan semakin banyak unsur hara yang tersedia untuh tanah dan meningkatkan produksi tanaman.

\section{Interaksi Antara Bahan Organik dan Pupuk Kandang terhadap Tinggi Tanaman Umur 15, 30 dan 45 HST.}

Rata-rata tinggi tanaman jagung manis akibat interaksi perlakuan bahan organik dan pupuk kandang pada umur 15, 30 dan 45 HST disajikan pada Tabel 13.

Tabel 13 menunjukkan bahwa tinggi tanaman jagung manis tertinggi pada umur 30 HST terdapat pada perlakuan $\mathrm{B}_{1} \mathrm{~K}_{1}$ sedangkan pada umur 45 HST didapatkan pada perlakuan $\mathrm{B}_{1} \mathrm{~K}_{3}$. Pada umur $30 \mathrm{HST}$, perlakuan $\mathrm{B}_{1} \mathrm{~K}_{1}$ tidak berbeda nyata dengan perlakuan $\mathrm{B}_{0} \mathrm{~K}_{1}, \mathrm{~B}_{0} \mathrm{~K}_{2}, \mathrm{~B}_{1} \mathrm{~K}_{2}, \mathrm{~B}_{1} \mathrm{~K}_{3}, \mathrm{~B}_{2}$ $\mathrm{K}_{1}, \mathrm{~B}_{2} \mathrm{~K}_{2}$ dan $\mathrm{B}_{2} \mathrm{~K}_{3}$, namun berbeda nyata dengan perlakuan $\mathrm{B}_{0} \mathrm{~K}_{0}, \mathrm{~B}_{0} \mathrm{~K}_{3}, \mathrm{~B}_{1} \mathrm{~K}_{0}$ dan $\mathrm{B}_{2} \mathrm{~K}_{0}$. pada umur $45 \mathrm{HST}$, perlakuan $\mathrm{B}_{1} \mathrm{~K}_{3}$ tidak berbeda nyata dengan perlakuan $\mathrm{B}_{0} \mathrm{~K}_{2}, \mathrm{~B}_{1} \mathrm{~K}_{1}, \mathrm{~B}_{1} \mathrm{~K}_{2}$ dan $\mathrm{B}_{2} \mathrm{~K}_{1}$, tetapi berbeda nyata dengan perlakuan $\mathrm{B}_{0} \mathrm{~K}_{0}, \mathrm{~B}_{0} \mathrm{~K} 1, \mathrm{~B}_{0} \mathrm{~K}_{3}, \mathrm{~B}_{1} \mathrm{~K}_{0}, \mathrm{~B}_{2} \mathrm{~K}_{0}, \mathrm{~B}_{2} \mathrm{~K}_{2}$ dan $\mathrm{B}_{2} \mathrm{~K}_{3}$.

Hal ini diduga Bahan organik ampas tebu dan jerami padi mamiliki kandungan mikroba yang rendah sehingga dengan penambahan pupuk kandang mampu menambah kandungan mikroba pada bahan organik. Pendapat Hartatik dkk (2015) bahwa pupuk organik yang berasal dari tumbuhan 
yang sudah mati, kotoran hewan atau limbah organik lainnya yang telah melalui proses rekayasa, bentuk padat atau cair dan dapat diperkaya dengan mineral atau mikroba yang bermanfaat untuk meningkatkan kandungan hara dan bahan organik tanah serta memperbaiki sifat fisik, kimia dan biologi tanah. Selanjutnya pendapat.

Tabel 13. Rata-rata Tinggi Tanaman Jagung Manis akibat Interaksi Bahan Organik dan Pupuk Kandang.

\begin{tabular}{clcl}
\hline \multirow{2}{*}{ Perlakuan } & \multicolumn{3}{c}{ Rata-Rata Tinggi Tanaman } \\
\cline { 2 - 4 } & $15 \mathrm{HST}$ & $30 \mathrm{HST}$ & $45 \mathrm{HST}$ \\
\hline $\mathrm{B}_{0} \mathrm{~K}_{0}$ & 13,92 & $38,12 \mathrm{a}$ & $55,18 \mathrm{a}$ \\
$\mathrm{B}_{0} \mathrm{~K}_{1}$ & 19,58 & $83,14 \mathrm{c}$ & $159,32 \mathrm{de}$ \\
$\mathrm{B}_{0} \mathrm{~K}_{2}$ & 20,50 & $79,69 \mathrm{c}$ & $164,53 \mathrm{def}$ \\
$\mathrm{B}_{0} \mathrm{~K}_{3}$ & 19,13 & $61,65 \mathrm{~b}$ & $93,42 \mathrm{c}$ \\
$\mathrm{B}_{1} \mathrm{~K}_{0}$ & 14,98 & $27,09 \mathrm{a}$ & $40,00 \mathrm{a}$ \\
$\mathrm{B}_{1} \mathrm{~K}_{1}$ & 22,00 & $89,74 \mathrm{c}$ & $176,62 \mathrm{def}$ \\
$\mathrm{B}_{1} \mathrm{~K}_{2}$ & 20,15 & $88,94 \mathrm{c}$ & $179,18 \mathrm{ef}$ \\
$\mathrm{B}_{1} \mathrm{~K}_{3}$ & 19,15 & $81,00 \mathrm{c}$ & $184,50 \mathrm{f}$ \\
$\mathrm{B}_{2} \mathrm{~K}_{0}$ & 16,45 & $38,40 \mathrm{a}$ & $71,9 \mathrm{~b}$ \\
$\mathrm{~B}_{2} \mathrm{~K}_{1}$ & 20,18 & $89,56 \mathrm{c}$ & $172,72 \mathrm{def}$ \\
$\mathrm{B}_{2} \mathrm{~K}_{2}$ & 20,40 & $85,12 \mathrm{c}$ & $159,70 \mathrm{de}$ \\
$\mathrm{B}_{2} \mathrm{~K}_{3}$ & 21,33 & $82,78 \mathrm{c}$ & $156,78 \mathrm{~d}$ \\
\hline $\mathrm{BNT}_{0,05}$ & tn & 17,00 & $20,80 \mathrm{cos}$ \\
\hline
\end{tabular}

Keterangan: Angka yang diikuti oleh huruf yang sama pada kolom yang sama berbeda tidak nyata pada uji BNT pada taraf $5 \%$

Rata-rata Diameter Pangkal Batang tanaman jagung manis akibat interaksi perlakuan bahan organik dan pupuk kandang pada umur 15, 30 dan 45 HST disajikan pada Tabel 14.

Tabel 14. Rata-rata Diameter Batang Tanaman Jagung Manis akibat Interaksi Bahan Organik dan Pupuk Kandang.

\begin{tabular}{clcl}
\hline \multirow{2}{*}{ Perlakuan } & \multicolumn{3}{c}{ Rata-Rata Diameter Batang } \\
\cline { 2 - 4 } & $15 \mathrm{HST}$ & $0,70 \mathrm{HST}$ & $45 \mathrm{HST}$ \\
\hline $\mathrm{B}_{0} \mathrm{~K}_{0}$ & 0,30 & $1,78 \mathrm{~cd}$ & $0,93 \mathrm{a}$ \\
$\mathrm{B}_{0} \mathrm{~K}_{1}$ & 0,65 & $1,90 \mathrm{cde}$ & $2,80 \mathrm{c}$ \\
$\mathrm{B}_{0} \mathrm{~K}_{2}$ & 0,67 & $1,22 \mathrm{~b}$ & $2,77 \mathrm{c}$ \\
$\mathrm{B}_{0} \mathrm{~K}_{3}$ & 0,53 & $0,47 \mathrm{a}$ & $1,97 \mathrm{~b}$ \\
$\mathrm{~B}_{1} \mathrm{~K}_{0}$ & 0,25 & $1,97 \mathrm{cdef}$ & $0,82 \mathrm{a}$ \\
$\mathrm{B}_{1} \mathrm{~K}_{1}$ & 0,73 & $2,30 \mathrm{f}$ & $2,62 \mathrm{c}$ \\
$\mathrm{B}_{1} \mathrm{~K}_{2}$ & 0,83 & $1,67 \mathrm{c}$ & $3,02 \mathrm{c}$ \\
$\mathrm{B}_{1} \mathrm{~K}_{3}$ & 0,53 & $0,82 \mathrm{a}$ & $2,65 \mathrm{c}$ \\
$\mathrm{B}_{2} \mathrm{~K}_{0}$ & 0,45 & $2,10 \mathrm{def}$ & $1,20 \mathrm{a}$ \\
$\mathrm{B}_{2} \mathrm{~K}_{1}$ & 0,68 & $2,17 \mathrm{ef}$ & $2,98 \mathrm{c}$ \\
$\mathrm{B}_{2} \mathrm{~K}_{2}$ & 0,75 & $1,78 \mathrm{~cd}$ & $2,87 \mathrm{c}$ \\
$\mathrm{B}_{2} \mathrm{~K}_{3}$ & 0,70 & 0,36 & $2,68 \mathrm{c}$ \\
\hline BNT 0,05 & tn & 0,42 \\
\hline
\end{tabular}

Keterangan: Angka yang diikuti oleh huruf yang sama pada kolom yang sama berbeda tidak nyata pada uji BNT pada taraf $5 \%$.

Tabel 14 menunjukkan bahwa diameter batang tanaman jagung manis tertinggi pada umur 30 dan 45 HST terdapat pada perlakuan $\mathrm{B}_{1} \mathrm{~K}_{2}$. . Pada umur $30 \mathrm{HST}$, perlakuan $\mathrm{B}_{1} \mathrm{~K}_{2}$ tidak berbeda nyata dengan perlakuan $\mathrm{B}_{1} \mathrm{~K}_{1}, \mathrm{~B}_{2} \mathrm{~K}_{1}$ dan $\mathrm{B}_{2} \mathrm{~K}_{2}$. Namun berbeda nyata dengan perlakuan $\mathrm{B}_{0} \mathrm{~K}_{0}, \mathrm{~B}_{0} \mathrm{~K}_{1}$, $\mathrm{B}_{0} \mathrm{~K}_{2}, \mathrm{~B}_{0} \mathrm{~K}_{3}, \mathrm{~B}_{1} \mathrm{~K}_{0}, \mathrm{~B}_{1} \mathrm{~K}_{3}, \mathrm{~B}_{2} \mathrm{~K}_{0}$, dan $\mathrm{B}_{2} \mathrm{~K}_{3}$. Pada umur $45 \mathrm{HST}$, perlakuan $\mathrm{B}_{1} \mathrm{~K}_{2}$ tidak berbeda nyata dengan perlakuan $\mathrm{B}_{0} \mathrm{~K}_{1}, \mathrm{~B}_{0} \mathrm{~K}_{2}, \mathrm{~B}_{1} \mathrm{~K}_{1}, \mathrm{~B}_{1} \mathrm{~K}_{3}, \mathrm{~B}_{2} \mathrm{~K}_{1}, \mathrm{~B}_{2} \mathrm{~K}_{2}$ dan $\mathrm{B}_{2} \mathrm{~K}_{3}$, berbeda nyata dengan perlakuan $\mathrm{B}_{0} \mathrm{~K}_{3} \quad \mathrm{~B}_{0} \mathrm{~K}_{0}, \mathrm{~B}_{1} \mathrm{~K}_{0}$, dan $\mathrm{B}_{2} \mathrm{~K}_{0}$. 
Hal ini diduga bahwa dengan interaksi perlakuan bahan organik dan pupuk kandang mampu merangsang pertumbuhan vegetatip tanaman akibat kandungan hara yang terdapat pada bahan organik dan pupuk kandang. Hal ini sesuai dengan pendapat Pramanda dkk (2015) bahwa pertumbuhan pada masa generatif tanaman memerlukan kandungan hara yang cukup untuk memaksimalkan pertubuhan tanaman sehingga dengan menambahkan bahan organik dan pupuk kandang mampu memperbaiki bagian sel dan jaringan-jaringan pada tanaman sehingga memerlukan karbohidrat, air serta hormon dan vitamin. Hal ini sangat erat kaitannya dengan serapan air serta zat hara.

\section{Interaksi Antara Bahan Organik dan Pupuk Kandang Terhadap Parameter Produksi Tanaman}

Rata-rata hasil produksi tanaman jagung manis akibat interaksi perlakuan bahan organik dan pupuk kandang disajikan pada Tabel 15.

Tabel 15. Rata-rata Hasil Produksi Tanaman Jagung Manis akibat Interaksi Bahan Organik Dan Pupuk Kandang.

\begin{tabular}{cccc}
\hline \multirow{2}{*}{ Perlakuan } & \multicolumn{3}{c}{ Hasil Produksi } \\
\cline { 2 - 4 } & Berat Tongkol Klobot & Panjang Tongkol & Produksi Perhektar \\
\hline $\mathrm{B}_{0} \mathrm{~K}_{0}$ & $101,5 \mathrm{a}$ & $16,20 \mathrm{~b}$ & $6,78 \mathrm{a}$ \\
$\mathrm{B}_{0} \mathrm{~K}_{1}$ & $218,17 \mathrm{c}$ & $20,70 \mathrm{de}$ & $14,54 \mathrm{c}$ \\
$\mathrm{B}_{0} \mathrm{~K}_{2}$ & $224,83 \mathrm{c}$ & $19,83 \mathrm{cde}$ & $14,98 \mathrm{c}$ \\
$\mathrm{B}_{0} \mathrm{~K}_{3}$ & $240,00 \mathrm{de}$ & $20,20 \mathrm{cde}$ & $16,00 \mathrm{de}$ \\
$\mathrm{B}_{1} \mathrm{~K}_{0}$ & $107,50 \mathrm{a}$ & $9,95 \mathrm{a}$ & $7,16 \mathrm{a}$ \\
$\mathrm{B}_{1} \mathrm{~K}_{1}$ & $235,33 \mathrm{~d}$ & $22,08 \mathrm{e}$ & $15,68 \mathrm{~d}$ \\
$\mathrm{~B}_{1} \mathrm{~K}_{2}$ & $238,17 \mathrm{de}$ & $20,67 \mathrm{de}$ & $15,87 \mathrm{de}$ \\
$\mathrm{B}_{1} \mathrm{~K}_{3}$ & $245,83 \mathrm{e}$ & $18,77 \mathrm{bcd}$ & $16,38 \mathrm{e}$ \\
$\mathrm{B}_{2} \mathrm{~K}_{0}$ & $124,00 \mathrm{~b}$ & $16,38 \mathrm{~b}$ & $8,26 \mathrm{~b}$ \\
$\mathrm{~B}_{2} \mathrm{~K}_{1}$ & $237,33 \mathrm{~d}$ & $20,88 \mathrm{de}$ & $15,82 \mathrm{~d}$ \\
$\mathrm{~B}_{2} \mathrm{~K}_{2}$ & $256,83 \mathrm{f}$ & $18,05 \mathrm{bc}$ & $17,12 \mathrm{f}$ \\
$\mathrm{B}_{2} \mathrm{~K}_{3}$ & $260,00 \mathrm{f}$ & $20,28 \mathrm{cde}$ & $17,33 \mathrm{f}$ \\
\hline $\mathrm{BNT}_{0,01}$ & 7,73 & 2,58 & 0,54 \\
\hline
\end{tabular}

Keterangan: Angka yang diikuti oleh huruf yang sama pada kolom yang sama berbeda tidak nyata pada uji (BNT) pada taraf $5 \%$.

Tabel 15 menunjukkan bahwa produksi tanaman tertinggi pada parameter berat tongkol berklobot dijumpai pada perlakuan $\mathrm{B}_{2} \mathrm{~K}_{3}$, parameter Panjang tongkol dijumpai pada perlakuan $\mathrm{B}_{1} \mathrm{~K}_{1}$ dan pada produksi perhektar nilai hasil tertinggi di jumpai pada perlakuan $\mathrm{B}_{2} \mathrm{~K}_{3}$. Parameter berat tongkol berklobot pada perlakuan $\mathrm{B}_{2} \mathrm{~K}_{3}$ tidak bepengaruh nyata dengan perlakuan $\mathrm{B}_{2} \mathrm{~K}_{2}$ namun berbeda nyata dengan perlakuan $\mathrm{B}_{0} \mathrm{~K}_{0}, \mathrm{~B}_{0} \mathrm{~K}_{1}, \mathrm{~B}_{0} \mathrm{~K}_{2}, \mathrm{~B}_{0} \mathrm{~K}_{3} \mathrm{~B}_{1} \mathrm{~K}_{0}, \mathrm{~B}_{1} \mathrm{~K}_{1}, \mathrm{~B}_{1} \mathrm{~K}_{2}, \mathrm{~B}_{1} \mathrm{~K}_{3} \mathrm{~B}_{2} \mathrm{~K}_{0}$ dan $\mathrm{B}_{2} \mathrm{~K}_{1}$. Parameter panjang tongkol $\mathrm{B}_{1} \mathrm{~K}_{1}$ tidak berbeda nyata dengan perlakuan $\mathrm{B}_{0} \mathrm{~K}_{1}, \mathrm{~B}_{0} \mathrm{~K}_{2}, \mathrm{~B}_{1} \mathrm{~K}_{2}, \mathrm{~B}_{2} \mathrm{~K}_{1}$ dan $\mathrm{B}_{2} \mathrm{~K}_{3}$, berbeda nyata dengan $\mathrm{B}_{0} \mathrm{~K}_{0}, \mathrm{~B}_{1} \mathrm{~K}_{0}, \mathrm{~B}_{1} \mathrm{~K}_{3}, \mathrm{~B}_{2} \mathrm{~K}_{0}$ dan $\mathrm{B}_{2} \mathrm{~K}_{2}$. selanjutnya para meter produksi per hektar pada perlakuan $\mathrm{B}_{2} \mathrm{~K}_{3}$ tidak berpengaruh nyata pada perlakuan $\mathrm{B}_{2} \mathrm{~K}_{2}$, namun berbeda nyata terhadap perlakuan $\mathrm{B}_{0} \mathrm{~K}_{0}, \quad \mathrm{~B}_{0} \mathrm{~K}_{1}, \quad \mathrm{~B}_{0} \mathrm{~K}_{2}, \quad \mathrm{~B}_{0} \mathrm{~K}_{3}, \quad \mathrm{~B}_{1} \mathrm{~K}_{0}, \quad \mathrm{~B}_{1} \mathrm{~K}_{1}, \quad \mathrm{~B}_{1} \mathrm{~K}_{2} \quad \mathrm{~B}_{2} \mathrm{~K}_{0}, \quad \mathrm{~B}_{1} \mathrm{~K}_{3}$ dan $\mathrm{B}_{2} \mathrm{~K}_{1}$ Hal ini diduga bahwa pupuk kandang membantu dekomposisi bahan organik secara tepat sehingga mampu meningkatkan kandungan unsur P pada tanah. Sesuai dengan pendapat Riswanto (2017) bahwa bahan organik memiliki mikroorganisme yang sedikit sehingga membutuhkan dekomposer untuk mendekomposisi bahan organik, maka bahan organik memerlukan kombinasi pupuk kandang. Pupuk kandang memiliki mikroorganisme yang tinggi sehingga lebih cepat mendekomposisikan bahan organik.

\section{KESIMPULAN DAN SARAN}

1. Pemberian bahan organik berpengaruh sangat nyata terhadap pertumbuhan tinggi tanaman dan diameter jagung manis umur 30 dan 45 HST, berat tongkol berklobot dan tanpa klobot, produksi perhektar dan $\mathrm{pH}$ tanah incept isol. Namun tidak berpengaruh nyata terhadap pertumbuhan 
tinggi tanaman, diameter batang pada umur 15 HST dan panjang tongkol jagung manis. hasil pengamatan terbaik diperoleh pada pelakuan bahan organik ampas tebu $\left(\mathrm{B}_{2}\right)$

2. Pemberian pupuk kandang berpengaruh sangat nyata terhadap parameter pengamatan seperti tinggi tanaman, diameter batang umur 30 dan 45 HST, berat tongkol berklobot dan tanpa klobot, panjang tongkol, produksi per hektar dan $\mathrm{pH}$ tanah inceptisol, namun tidak berpengaruh nyata terhadap tinggi tanaman dan diameter batang pada umur 15 HST. Hasil pengamatan terbaik diperoleh pada perlakuan pemberian pupuk kandang ayam $\left(\mathrm{K}_{3}\right.$

3. Interaksi antara perlakuan jenis bahan organik dan pupuk kandang berpengaruh sangat nyata terhadap tinggi tanaman, diameter batang pada umur 30 dan 45 HST, berat tongkol berklobot dan tanpa klobot, panjang tongkol, produksi perhektar dan $\mathrm{pH}$ tanah inceptisol. Namun tidak berpengaruh nyata terhadap tinggi tanaman, diameter batang umur 15 HST. Interaksi terbaik terhadap parameter pengamatan dijumpai pada kombinasi perlakuan pemberian ampas tebu dan pupuk kandang ayam $\left(\mathrm{B}_{2} \mathrm{~K}_{3}\right)$.

\section{DAFTAR PUSTAKA}

Adnan, K. 2015. Pengaruh Pupuk Kandang Ayam dan N, P, K terhadap Pertumbuhan dan Produksi Jagung Manis (Zea mays saccharata Sturt) di Tanah Ultisol. Jurnal Faperta. 2 (1): 1-12

Budiman. A. 2014. Aplikasi Kascing dan Cendawan Mikoriza Abuskula (CMA) pada Tanah Ultisol serta Efeknya terhadap Perkembangan Mikroorganisme Tanah dan Hasil Tanaman Jagung (Zea mays L). Skripsi. Program Studi Agroteknologi. Fakultas Pertanian. Universitas Andalas.

Hartatik. W., Husnain., Ladiyani R. Widowati. 2015. Peranan Pupuk Organik dalam Peningkatan Produktivitas Tanah dan Tanaman.Makalah Review. 1907-0799

Jumini., Nurhayati., Murzani. 2011. Efek

Kombinasi Dosis Pupuk N. P. K dan

Cara Pemupukan terhadap Pertumbuhan dan Hasil Jagung. Jurnal Floratek. 6 (1): 65-170

Kresnatita, S., Koesriharti., Santoso, M. 2013. Pengaruh Rabuk Organik terhadap Pertumbuhan dan Hasil Tanaman Jagung Manis (Zea mays Saccharata Sturt). Jurnal Indonesia Green Technologi. 2 (1) : 8-17

Mapegau. 2010. Pengaruh Pemupukan N dan P terhadap Pertumbuhan dan Hasil Tanaman Jagung Manis. JurnalPenelitian Universitas Jambi. 12 (2) : 33-36

Marinda, C. P., Wardinati, Y., Susanti,I. H. 2016. Pengaruh Kompos Ampas Tebu (Saccarum Officinarum) terhadap Pertumbuhan dan Produktivitas Tanaman Sawi Manis (Brassisca juncea. L). Jurnal Budidaya Tanaman. 1 (2) : 1-9

Marvelia., Darmanti. S., Parman. S. 2006. Produksi Tanaman Jagung Manis (Zea mays L. Saccarata) yang Diperlakukan dengan Kompos Kascing dengan Dosis yang Berbeda. Jurnal Agronomi dan Fisiologi 517 (2)

Ningsih. D. N., Marlina. N., Hawayanti. E. 2015. Pengaruh Jenis Pupuk Organik terhadap Pertumbuhan dan Produksi Jagung Manis (Zea mays saccharata Sturt). Skiripsi. Program Studi Agroteknologi. Fakultas Pertanian. Universitas Muhammadiyah Palembang.

Nurcahaya. A. A., N. Herlina. Bambang. G. 2017. Pengaruh Macam Pupuk Organik dan Waktu Aplikasi terhadap Pertumbuhan dan Hasil Jagung Manis (Zea mays saccharata Sturt). Jurnal Produksi Tanaman. 5 (9) : 1476-1482

Parman. 2007. Pengaruh Pupuk Oraganik Cair terhadap Pertumbuhan Tanaman Kentang (Solanum tuberosum L. Skripsi .Program Studi Biologi.Fakultas Matematika dan Ilmu Pengetahuan Alam. Universitas Semarang.

Pramanda. R. P., Kuswanta. F., Hidayat., Sunyoto., Kamal. M. 2015. Pengaruh Aplikasi Bahan Organik terhadap Pertumbuhan dan Hasil Beberapa Varietas Sorgum(Sorgum bicolor L.). Jurnal Agroteknologi Tropika. 3 (1). 85-91

Puslitbangtanak. 2003. Atlas Tata Ruang Pertanian Nasional Skala 1:1.000.000. Departemen Pertanian Repuplik Indonesia. Bogor

Resman., Samsul., Sirads, A.,Bambang, H. S. 2006. Kajian Beberapa Sifat Kimia dan Fisika Inceptisol pada Toposkuen Lereng Selatan Gunung Merapi Kabupaten Sleman.Jurnal Ilmu Tanah dan Lingkungan. 5 (1) : 673-681 
Riswanto. H., 2017. Pengaruh Berbagai Macam Pupuk Kandang terhadap Pertumbuhan dan Hasil Beberapa Varietas Jagung ( Zea mays L). Skripsi. Program Studi Agroteknologi. Fakultas Pertanian. Universitas PGPRI Yogyakarta

Saputra, I. 2015. Respon Pertumbuhan dan Hasil Ja gung Manis (Zea mays L) Akibat Perbedaan Jenis dan Dosis Bahan Organik pada Tanah Ordo Inceptisol. Jurnal Agrosamudra. 2(2) : 29-39

Sholeha. M. 2011. Respon Pertumbuhan dan produksi Tanaman Jagung (Zea Mays) Akibat Perlakuan Dosis Bantuan Fosfat. Skripsi. Program Studi Ilmu Tanah. Fakultas Pertanian. Universitas Jember.

Sidar. 2010. Pengaruh Kompos Sampah Kota dan Pupuk Kandang Ayam terhadap Beberapa Sifat Kimia Tanah dan hasil tanaman Jagung Manis (Zea mays saccharat Sturt). Artikel Ilmiyah. Fluventik Eutrupdepts. Sumedang.

Simanungkalit. R. D. M., Didi. A.S., Saraswati. R., Setiyorini., Wiwik. H. 2006. Pupuk Organik dan Pupuk Hayati. Balai Besar Penelitian dan Pengembangan Sumber Daya Lahan Pertanian Bogor. Hal 1-10

Sutanto, R. 2005. Penerapan Pertanian Organik (Pemasyarakatan dan Pengembangannya). Penerbit Kanisius. Yogyakarta

Tan. K. H. Environ Mental Soil Science. Marred Dekker. Inc. New York.

Taufiq, A., Yetti, H.2016. Pengaruh Pemberian Pupuk Kandang Ayam dan Pupuk N terhadap Pertumbuhan dan Produksi Jagung Manis (Zea mays sacchara Sturt).Jurnal Faperta. 3. (2) $: 1-12$

Wahyudin. A., Fitriatin. B. N., Wicaksono. F. Y., Ruminta. A., Rahadiyan. 2017. Respon Tanaman Jagung (Zea mays L.) akibat Pemberian Pupuk Fosfat dan Waktu Aplikasi Pupuk Hayati Mikroba Pelarut Fosfat pada Ultisol Jatinangor. Jurnal Kultivasi. 16 (1)

Wahyuni. E. 2017. Pengaruh dosis Pupuk Kandang Biri-Biri dan Pupuk Hayati MitraTani Terhadap Pertumbuhan dan Hasil Jagung Manis (Zea mays saccarata Sturt). Skripsi. Program Studi Agroteknologi. Fakultas Pertanian. Universitas Samudra. Langsa

Wiryanto., 2003. Pengaruh Komposisi Makrofauna Tanah terhadap Dekomposisi Bahan Organik Tanaman dan Pertumbuhan Jagung (Zea mays L). Universitas Sebelas Maret Surakarta. 7 : $110-114$ 